\title{
Pengaruh Rasio Keuangan Terhadap Harga Saham
}

\author{
Sheila Silvia Permatasari ${ }^{1 *}$ dan Mukaram ${ }^{2}$ \\ ${ }^{1}$ Administrasi Niaga, Politeknik Negeri Bandung, Indonesia \\ ${ }^{2}$ Administrasi Niaga, Politeknik Negeri Bandung, Indonesia
}

\begin{abstract}
:
This study aims to influence the financial ratios of stock prices on issuers of automotive sector companies and components listed on the Indonesia Stock Exchange period 2011-2016. This study is a documentation study, where the data used is a secondary data obtained from company reports that have been available. The population in this research is all companies of automotive sector and components listed in IDX and reporting company's finance in period 2011-2016. From a total of 13 companies, 12 companies were taken as samples because one company did not meet the requirements of the financial statements for the period in this study. Data analysis was done by multiple linear regression analysis and hypothesis test by using $t$ test and $F$ test. The result showed that DERand PER have negative and significant effect to stock price in automotive company and component listed on IDX 2011-2016, TATO has a positive and insignificant effect on stock prices in automotive companies and components listed on IDX 2011-2016, CR and ROA have negative and significant effect to stock price in automotive company and component listed on IDX 2011-2016.
\end{abstract}

Keywords: financial ratios, stock prices, automotive sector companies and components

\section{PENDAHULUAN}

Industri otomotif Indonesia telah menjadi sebuah pilar penting dalam sektor manufaktur negara ini, karena tidak sedikit perusahaan mobil yang terkenal di dunia membuka pabrik-pabrik manufaktur mobil atau meningkatkan kapasitas produksinya di Indonesia. Indonesia memiliki industri manufaktur mobil terbesar kedua di Asia Tenggara dan di wilayah ASEAN setelah Thailand yang menguasai sekitar 50 persen dari produksi mobil. Kendati begitu, karena pertumbuhannya yang subur di beberapa tahun terakhir, Indonesia akan semakin mengancam posisi dominan Thailand selama satu dekade mendatang. Namun, untuk

*Email korespondensi:

Sheila Silvia Permatasari

Sheila.silvia.abs414@polban.ac.id mengambil alih posisi Thailand sebagai produsen mobil terbesar di kawasan ASEAN, akan memerlukan upaya dan terobosan besar. Saat ini, Indonesia sangat tergantung pada investasi asing langsung, terutama dari Jepang, untuk pendirikan fasilitas manufaktur mobil. Indonesia juga perlu mengembangkan industri komponen mobil yang bisa mendukung industri manufaktur mobil.

Jika dilihat dari ukuran pasar, Indonesia merupakan pasar mobil terbesar di Asia Tenggara dan wilayah ASEAN. Indonesia menguasai sekitar sepertiga dari total penjualan mobil tahunan di ASEAN, diikuti oleh Thailand pada posisi kedua. Indonesia tidak hanya memiliki populasi besar, sekitar 258 juta jiwa, tetapi juga ditandai dengan memiliki kelas menengah 
yang berkembang pesat. Bersama-sama, kedua faktor ini menciptakan kekuatan konsumen yang kuat.

Menurut data Gaikindo (2018), pada tahun 2013, penjualan kendaraan otomotif di Indonesia mencapai 1.229.811 unit. Tahun selanjutnya, penjualan menurun menjadi 1.208.028 unit. Penurunan terus terjadi hingga tahun 2015 dengan jumlah penjualan 1.013.518 unit. Namun, pada tahun 2016, penjualan kembali meningkat menjadi 1.062.716 unit dan 1.079.534 unit pada tahun 2017. Meskipun sempat mengalami penurunan, namun penjualan kendaraan otomotif dari tahun ke tahun tetap bertahan diangka satu juta. Hal ini dapat dilihat dari pembukaan pabrik baru oleh PT Mitsubishi Motors Krama Yudha Indonesia dan PT SGMW Motor Indonesia pada 2017. Disamping itu, fokus pemerintah terkait pengembangan infrastruktur di luar Pulau Jawa akan mendorong peningkatan pasar otomotif dalam negeri, khususnya di luar Pulau Jawa. Distribusi mobil akan berhubungan dengan pemerataan pembangunan. Dengan fokus pemerataan pembangunan, infrastruktur ke daerah di luar Jawa, khususnya ke wilayah Indonesia timur, diharapkan akan tersebar pusat-pusat kegiatan ekonomi di daerah yang secara tidak langsung diikuti distribusi kendaraan ke daerah-daerah.

Penjualan kendaraan otomotif yang relatif besar diangka satu juta, sejalan dengan data jumlah kendaraan bermotor di Indonesia yang terus meningkat. Pada tahun 2013, jumlah kendaraan bermotor di Indonesia sebesar 104.118.969 unit. Di tahun 2014, jumlah kendaraan meningkat sebesar 10.090.291 unit. Peningkatan jumlah kendaraan terus terjadi di tahun 2015 dan 2016 dengan peningkatan sebesar 7.184.925 unit di tahun 2015 dan 7.886 .894 unit di tahun 2016 dari tahun sebelumnya.
Tabel 1 Jumlah Kendaraan Bermotor di Indonesia

\begin{tabular}{|l|r|r|r|r|}
\hline $\begin{array}{l}\text { Jenis Kendaraan } \\
\text { Bermotor }\end{array}$ & \multicolumn{1}{|c|}{2013} & 2014 & \multicolumn{1}{c|}{2015} & \multicolumn{1}{c|}{2016} \\
\hline & & & & \\
\hline Mobil Penumpang & 11.484 .514 & 12.599 .038 & 13.480 .973 & 14.580 .666 \\
\hline Mobil Bis & 2.286 .309 & 2.398 .846 & 2.420 .917 & 2.486 .898 \\
\hline Mobil Barang & 5.615 .494 & 6.235 .136 & 6.611 .028 & 7.063 .433 \\
\hline Sepeda motor & 84.732 .652 & 92.976 .240 & 98.881 .267 & 105.150 .082 \\
\hline \multicolumn{1}{|c|}{ Jumlah } & 104.118 .969 & 114.209 .260 & 121.394 .185 & 129.281 .079 \\
\hline
\end{tabular}

Sumber: Badan Pusat Statistik (2018)

Meningkatnya jumlah kendaraan bermotor di Indonesia dan tingginya penjualan kendaraan bermotor, tidak terlepas dari peran pemerintah. Peran pemerintah dalam upaya untuk mengoptimalkan industri otomotif dalam negeri yaitu dengan mengeluarkan kebijakan yang berkaitan dengan mobil murah atau yang lebih dikenal dengan Low Cost Green Car (LCGC). Dukungan tersebut semakin nyata dengan di tetapkannya Peraturan Pemerintah Republik Indonesia Nomor 41 Tahun 2013 tentang "barang kena pajak yang tergolong mewah berupa kendaraan bermotor yang dikenai pajak penjualan atas barang mewah" pada tanggal 23 Mei 2013. Dilihat dari isi peraturan tersebut, subjek yang dituju jelas merupakan kendaran bermotor berjenis mobil yang memiliki roda empat atau lebih.

Terkait program mobil hemat energi dan harga murah, tujuan yang ingin dicapai adalah mendorong peningkatan kapasitas produksi, sehingga terjadi peningkatan investasi, penambahan tenaga kerja, bahkan ekspor produk otomotif dengan ASEAN sebagai pasar utama. Dalam rangka peningkatan investasi, salah satu investasi yang dapat dilakukan oleh para investor adalah investasi pada pasar modal yang memiliki banyak produk investasi. Di Indonesia, terdapat pasar modal yang bernama Bursa Efek Indonesia (BEI) adalah bursa efek yang berbasis di Jakarta, Indonesia. Sebelumnya dikenal sebagai Bursa Efek Jakarta (BEJ) sebelum namanya berubah pada tahun 2007 setelah bergabung 
dengan Bursa Efek Surabaya (BES). Bursa ini memiliki peranan penting dalam perkembangan perekonomian negara karena dapat memberikan sarana bagi masyarakat umum untuk berinvestasi dan sebagai sarana untuk mencari tambahan modal bagi perusahaan go public. Di Indonesia sendiri, kinerja operasional hingga pertengahan tahun 2017 sedang mengalami beberapa peningkatan seperti yang dicatat oleh KSEI dan digambarkan dalam Gambar 1

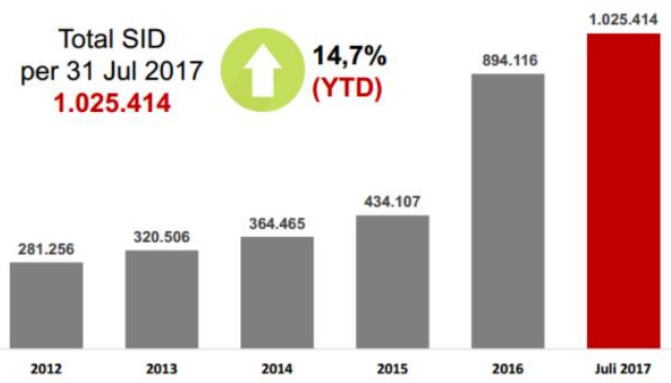

Gambar 1 Pertumbuhan SID 2012 - Juli 2017

Berdasarkan Gambar 1, jumlah Single Investor Identification (SID) meningkat $14,7 \%$ dari 894.116 per tahun 2016 menjadi 1.025.414 per Juli tahun 2017. Gambar dari grafik tersebut juga menunjukan bahwa selalu ada kenaikan dari tahun 2012 hingga tahun 2017. Direktur Utama KSEI turut mengatakan bahwa per Juni 2017, KSEI mencatat rekor baru jumlah investor pasar modal Indonesia yang telah menembus angka 1 juta. Jumlah tersebut merupakan jumlah SID terkonsolidasi yang terdiri dari investor pemilik Saham, Surat Utang, Reksa Dana, Surat Berharga Negara (SBN) dan Efek lain yang tercatat di KSEI.

Kenaikan yang terjadi pada jumlah investor pasar modal tentu tidak terlepas dari peran KSEI. Selaku lembaga penyimpanan dan penyelesaian, KSEI melakukan serangkaian pengembangan infrastruktur untuk memberikan kemudahan dan kenyamanan bagi investor dan pelaku pasar. Hal ini sejalan dengan upaya OJK dan SRO untuk meningkatkan jumlah investor, khususnya investor lokal. Sejak tahun 2016, KSEI menggandeng Ditjen Kependudukan dan Pencatatan Sipil, Kementerian dalam Negeri Republik Indonesia untuk proses percepatan pembukaan rekening investasi pasar modal. Dengan memanfaatkan data Kependudukan dan Kartu Tanda Penduduk Elektronik untuk layanan jasa pasar modal, maka proses pembukaan rekening Efek yang sebelumnya membutuhkan waktu beberapa hari, kini hanya membutuhkan waktu kurang dari 30 menit. Serangkaian pengembangan yang dijalankan itu cukup berperan dalam kenaikan jumlah investor lokal pada tahun 2016 dan 2017 yang terdapat pada Gambar 2 dan Gambar 3

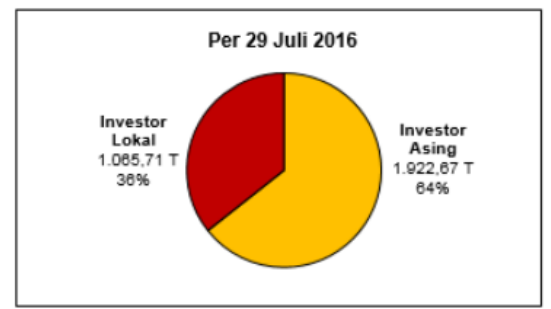

\section{Gambar 2 Komposisi Kepemilikan Saham 2016}

Dari sisi kepemilikan yang terdapat di kedua grafik tersebut, investor lokal telah mengalami kenaikan sebesar $11 \%$ dari tahun sebelumnya. Hal tersebut tentu merupakan angin segar untuk investor lokal karena setidaknya serangkaian pengembangan yang dilakukan beberapa lembaga dapat sampai hingga masyarakat lokal.

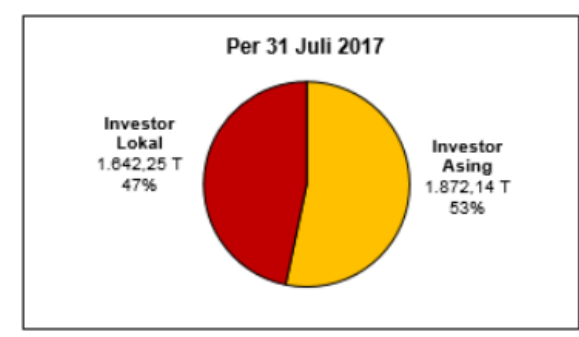

\section{Gambar 3 Komposisi Kepemilikan Saham 2017}

Kenaikan sisi kepemilikan saham juga diiringi dengan kenaikan indeks harga saham gabungan (IHSG) pada sepuluh tahun terakhir (2007-2017). Dari statistik sejarah 
kinerja IHSG 10 tahun terakhir pada Tabel 1.3 , seorang investor mendapat keuntungan sebesar $131,47 \%$ selama 10 tahun, atau setara 8,75\% jika disetahunkan. Uang Rp 1.000 .000 diinvestasikan sejak awal 2008 akan menjadi Rp2.314.658,69 pada akhir 2017. Hal tersebut terlihat rendah karena kinerja awal IHSG pada 2008 mengalami penurunan, berbeda dengan masa 10 tahun periode persis setahun sebelumnya.

Tabel 2 Kinerja IHSG 10 Tahun Terakhir

\begin{tabular}{|c|c|c|c|}
\hline Tahun & $\begin{array}{l}\text { IHSG } \\
\text { Akhir } \\
\text { Tahun }\end{array}$ & $\begin{array}{c}\text { Perolehan } \\
\text { Tahunan }\end{array}$ & $\begin{array}{l}\text { Akumulasi } \\
\text { Perolehan }\end{array}$ \\
\hline 2007 & $2.745,83$ & Nilai awal & Nilai awal \\
\hline 2008 & $1.355,41$ & $0,64 \%$ & $4 \%$ \\
\hline 2009 & $2.534,36$ & & $-7,70 \%$ \\
\hline 2010 & $3.703,51$ & $46,13 \%$ & $34,88 \%$ \\
\hline 2011 & $3.821,99$ & $3,20 \%$ & $39,19 \%$ \\
\hline 2012 & $4.316,69$ & $12,94 \%$ & $57,21 \%$ \\
\hline 2013 & $4.274,18$ & $-0,98 \%$ & $55,66 \%$ \\
\hline 2014 & 5.226 .95 & $22,29 \%$ & $90,36 \%$ \\
\hline 2015 & $4.593,01$ & & $67,27 \%$ \\
\hline 2016 & $5.296,71$ & & \\
\hline 2017 & $6.355,65$ & $19,99 \%$ & $131,47 \%$ \\
\hline \multicolumn{3}{|c|}{ Kinerja IHSG disetahunkan: } & $8,75 \%$ \\
\hline
\end{tabular}

Kenaikan IHSG tentu berpengaruh terhadap harga saham perusahaan Otomotif dan Komponen. Fenomena kenaikan harga saham di atas berimbas pada perusahaan sektor otomotif dan komponen yang terdaftar di Bursa Efek Indonesia (BEI).

Berdasarkan data keadaan ROA, DER, dan harga saham perusahaan sektor otomotif dan komponen periode 2011-2014, setiap tahunnya mengalami fluktuasi. Tingkat pengembalian aset (ROA) PT Astra Otoparts Tbk pada tahun 2014 mengalami peningkatan tetapi berbanding terbalik dengan harga sahamnya yang mengalami penurunan. Berdasarkan laporan keuangan tahunan, hal ini diindikasikan karena daya beli masyarakat yang menurun akan produk otomotif sehingga mengakibatkan penjualan otomotif relatif stagnan, serta pada tahun Jurnal Riset Bisnis dan Investasi yang sama terjadi kenaikan harga baku impor karena nilai tukar melonjak. Dengan adanya permasalahan tersebut, daya tarik investor terhadap saham perusahaan otomotif menurun. Hal ini tidak sesuai dengan teori yang ada, dimana menurut Lestari dan Sugiharto (2007: 196), semakin tinggi ROA maka semakin baik produktivitas aset dalam memperoleh keuntungan bersih. Hal tersebut selanjutnya akan meningkatkan daya tarik perusahaan kepada investor. Peningkatan daya tarik perusahaan menjadikan perusahaan tersebut semakin diminati oleh investor sehingga nantinya dapat meningkatkan harga saham perusahaan tersebut.

Selanjutnya adalah perusahaan PT Gajah Tunggal yang mana pada tahun 2011 dan 2012 mengalami peningkatan ROA dan mengalami penurunan DER. Namun, hal tersebut berbanding terbalik dengan harga sahamnya yang mengalami penurunan. Hal ini tidak sesuai dengan teori yang ada dimana menurut Ang (1997:18.35), semakin besar DER menunjukkan semakin besar biaya hutang yang harus dibayar perusahaan, maka berdampak pada profitabilitas yang semakin berkurang. Hal ini menyebabkan hak para pemegang saham akan semakin berkurang, sehingga akan berpengaruh pada minat investor yang juga akan mempengaruhi harga saham. Pada tahun 2014, tingkat pengembalian aset PT Gajah Tunggal berada pada titik terendah dibandingkan tahun sebelumnya. Berdasarkan laporan tahunan, hal tersebut diindikasikan karena laba yang diterima perusahaan berkurang akibat meningkatnya beban biaya operasional terutama biaya transportasi serta gaji dan tunjangan. Tingginya biaya transportasi merupakan akibat dari kenaikan biaya pengiriman ke Amerika Serikat, destinasi ekspor perusahaan yang terbesar, serta meningkatnya biaya logistik di Indonesia. 
Selain itu, tingkat pengembalian aset PT Selamat Sempurna, Tbk pada tahun 2014 mengalami peningkatan dan rasio hutang atas modal mengalami penurunan, tetapi berbanding terbalik dengan harga sahamnya yang mengalami penurunan. Hal ini tentu tidak sesuai dengan teori yang ada. Hal yang berbanding terbaik terjadi pada perusahaan PT Indokordsa, Tbk ditahun 2011. Tingkat pengembalian aset perusahaan tersebut berada pada nilai terendah, hal ini diindikasikan karena pada tahun 2011 terjadi penurunan perolehan laba usaha. Namun, pada tahun 2012 tingkat pengembalian aset mengalami peningkatan dan rasio hutang atas modal mengalami penurunan. Meskipun demikian, hal tersebut berbanding terbalik dengan harga sahamnya yang mengalami penurunan, sehingga tidak sesuai dengan teori yang ada.

Hal yang sama terjadi pada perusahaan PT Multi Prima Sejahtera, Tbk. Pada tahun 2012, tingkat pengembalian aset perusahaan tersebut mengalami peningkatan dan rasio hutang atas modal mengalami penurunan, tetapi berbanding terbalik dengan harga sahamnya yang mengalami penurunan. Hal ini tidak sesuai dengan teori yang ada. Demikian pula dengan PT Indospring Tbk. Pada tahun 2012, rasio hutang atas modal mengalami penurunan tetapi berbanding terbalik dengan harga sahamnya yang menurun. Hal ini tidak sesuai dengan teori yang ada.

Fenomena yang terjadi pada perusahaan sektor sektor otomotif dan komponen, diperkuat dengan adanya artikel yang memuat bahwa pada tahun 2012, Bank Indonesia (BI) mengeluarkan aturan tentang minimum down payment (DP) atau peningkatan uang muka kredit kendaraan bermotor. Aturan ini langsung ditanggapi negatif dari pelaku industri terkait, seperti industri otomotif dan multifinance, hal tersebut mengakibatkan turunnya daya beli. BI menetapkan DP minimal 25\% untuk pembelian kendaraan bermotor roda dua dan DP minimal 20\% untuk pembelian kendaraan bermotor roda empat. Hal ini langsung mengakibatkan menurunnya harga saham perusahaan sektor otomotif karena para investor menanggapi ketentuan yang dikeluarkan oleh Bank Indonesia tersebut akan berdampak buruk terhadap kinerja perusahaan otomotif kedepannya.

Selain berdampak pada produsen kendaraan bermotor dengan adanya kebijakan Bank Indonesia menaikan uang muka kredit kendaraan bermotor, akan berpengaruh juga terhadap perusahaan komponen yang terdaftar di Bursa Efek Indonesia. Keterkaitan antara produsen kendaraan bermotor dengan perusahaan komponen yang terdaftar di Bursa Efek Indonesia terlihat jelas karena tidak sedikit produsen kendaraan bermotor bekerja sama dengan perusahaan komponen dalam memproduksi sebuah kendaraan bermotor baik roda empat ataupun roda dua. Sehingga apabila terjadi penurunan penjualan kendaraan bermotor maka otomatis pendapatan atau penjualan akan komponen otomotif juga akan berkurang dan akan berdampak pada menurunnya minat investor untuk menanamkan modalnya pada saham perusahaan sektor sektor otomotif dan komponen, karena dinilai dengan menurunnya daya beli masyarakat terhadap produk-produk otomotif, akan mengakibatkan keuntungan berupa deviden yang akan diterima investor akan ikut berkurang juga.

Dengan demikian, untuk mengurangi dampak yang mengakibatkan keuntungan, maka para investor memerlukan berbagai informasi sebagai pedoman untuk memutuskan investasi di pasar modal. Pada umumnya, para investor akan melakukan 
analisis sekuritas untuk mengetahui apakah saham yang akan dibeli dapat memberikan keuntungan bagi mereka atau justru akan memberikan kerugian. Terdapat dua pendekatan untuk menganalisis harga saham dan memilih saham, yaitu analisis teknikal dan analisis fundamental.

Analisis fundamental sebagai alat analisis saham dipilih karena dianggap dapat memberikan informasi mengenai kondisi kinerja keuangan perusahaan yang berdampak pada laba yang dihasilkan perusahaan tersebut. Jika suatu perusahaan yang memiliki kinerja keuangan yang baik maka akan dapat menghasilkan laba yang besar. Dengan laba yang besar maka pembagian dividen kepada pemegang saham akan besar juga. Tingginya dividen yang dibagikan kepada pemegang saham akan berpengaruh pada harga saham di pasar saham.

Untuk dapat memperoleh gambaran perkembangan finansial perusahaan perlu mengadakan analisis atau interpretasi terhadap data keuangan dari perusahaan yang bersangkutan, dimana data tersebut dapat tercermin dari laporan keuangan. Ukuran yang sering digunakan dalam analisis fundamental adalah rasio keuangan. Rasio keuangan tersebut adalah likuiditas, solvabilitas, profitabilitas, aktivitas dan nilai pasar.

Berdasarkan beberapa data di atas, akan dikaji lebih dalam mengenai pengaruh current asset (CR), debt to equity ratio (DER), return on asset (ROA), total asset turnover (TATO), dan price earning ratio (PER) terhadap harga saham. Oleh karena itu, diambil judul "Pengaruh Rasio Keuangan Terhadap Harga Saham".

\section{KAJIAN LITERATUR \\ Rasio Keuangan}

Osisioma dalam Enekwe (2015), mendefinisikan rasio keuangan sebagai interpretasi, penguatan dan penerjemahan fakta dan data yang terkandung dalam laporan keuangan, tujuannya adalah penarikan kesimpulan yang relevan sehingga membuat kesimpulan untuk operasi bisnis, posisi keuangan dan prospek masa depan. Menurut Arkan (2016), rasio keuangan didefinisikan sebagai nilai numerik yang dibuat dari dua atau lebih nilai yang diambil dari laporan keuangan perusahaan yaitu neraca, laporan laba rugi atau laporan arus kas. Biasanya, rasio keuangan disajikan sebagai metrik yang diukur dalam bentuk persentase, banyak atau rasio yang bertujuan untuk mengevaluasi kinerja keuangan, operasional dan daya saing perusahaan. Lain halnya dengan Igben dalam Nuhu (2014) yang berpendapat bahwa rasio keuangan adalah proporsi atau fraksi atau persentase yang menyatakan hubungan antara satu item dalam satu set laporan keuangan dan item lain dalam laporan keuangan. Berdasarkan beberapa definisi di atas, dapat disimpulkan bahwa rasio keuangan merupakan proses penyederhanaan informasi yang menggambarkan hubungan antara pos tertentu dengan pos lainnya.

Menurut Arkan (2016) yang ruang lingkup rasio keuangan terbagi menjadi lima kelompok, yaitu:

1. Rasio Leverage (Debit)

Kelompok rasio keuangan ini menunjukkan persentase struktur modal perusahaan yang terdiri atas utang atau kewajiban yang terhutang kepada pihak eksternal, juga berfokus pada kemampuan perusahaan untuk memenuhi kewajiban utang jangka panjangnya. 
2. Rasio Likuiditas (Solvabilitas)

Kelompok rasio likuiditas atau solvabilitas berfokus pada kemampuan perusahaan (aset lancar dan kewajiban lancar) untuk memenuhi kewajiban utang jangka pendeknya.

3. Rasio Operasi Keuangan

Kelompok rasio operasi keuangan yang kadang-kadang disebut rasio manajemen aset, mengukur efisiensi di mana perusahaan mengelola dan mengendalikan asetnya (memanfaatkan modalnya) dalam menghasilkan penjualan dan pendapatan.

4. Profitabilitas Rasio Keuangan

Kelompok rasio profitabilitas, juga dikenal sebagai rasio kinerja, menilai kemampuan perusahaan untuk memperoleh laba atas penjualan, aset dan ekuitas, mengukur laba yang diperoleh dari modal perusahaan dan bantalan keuangan relatif terhadap setiap dolar penjualan.

5. Rasio Penilaian (Rasio Nilai Pasar)

Rasio ini adalah rasio yang cenderung dilihat investor setiap hari dan berubah setiap saat harga saham berubah.

\section{Harga Saham}

Menurut Darmadji dan Fakhruddin dalam Mujiono (2017), harga saham adalah harga yang terjadi di lantai bursa pada waktu tertentu, harga saham dapat berubah naik atau turun dalam hitungan waktu yang begitu cepat, baik dalam hitungan menit maupun hitungan detik. Sedangkan Jogiyanto dalam Putri (2015) mengatakan bahwa harga saham adalah harga yang terjadi dipasar bursa pada saat tertentu yang ditentukan oleh pelaku pasar dan ditentukan oleh permintaan dan penawaran saham yang bersangkutan dipasar modal. Najib (2017) berpendapat bahwa harga saham juga dapat diartikan sebagai harga yang dibentuk dari interaksi para

penjual dan pembeli saham yang dilatar belakangi oleh harapan mereka terhadap profit perusahaan, untuk itu investor memerlukan informasi yang berkaitan dengan pembentukan saham tersebut dalam mengambil keputusan untuk menjual atau membeli saham. Berdasarkan ketiga pendapat tersebut, dapat disimpulkan bahwa harga saham merupakan salah satu indikator keberhasilan dalam pengelolaan perusahaan sehingga semakin tinggi harga saham yang ada di pasar atas suatu perusahaan tertentu, maka dapat diartikan perusahaan tersebut dapat mengelola aktiva dengan baik.

Jogiyanto dalam Munggaran, Mukaram, dan Sarah (2017) mengatakan bahwa kenaikan dan penurunan saham tidak terlepas dari peran informasi. Informasi tersebut dapat dikelompokkan menjadi 3 jenis, yaitu

1. Informasi yang bersifat fundamental, informasi ini berkaitan dengan perusahaan, seperti laporan keuangan dan kinerja manajemen perusahaan,informasi yang bersifat teknis,

2. Informasi ini mencerminkan kondisi perdagangan ekonomi, fluktuasi kurs dan volume transaksi, volume dan frekuensi tansaksi serta kekuatan pasar,

3. Informasi yang berkaitan dengan lingkungan, informasi ini berkaitan dengan kondisi ekonomi, politik dan keamanan negara, tingkat inflansi, dan kebijakan moneter.

\section{METODE PENELITIAN}

Metode penelitian yang digunakan dalam penelitian ini adalah metode deskriptif dengan pendekatan kuantitatif. Adapun data yang digunakan adalah data sekunder berupa laporan keuangan perusahaan di sektor otomotif dan komponenyang telah tersedia di Bursa Efek Indonesia. Setelah data sekunder 
yang diproleh, maka dilakukan penarikan sampel dengan kriteria-kriteria tertentu. Kemudian, data sekunder tersebut dilakukan pemodelan data panel yang menggabungkan data silang (cross section) dengan data deret waktu (time series). Menurut Gujarati dan Porter (2009) mengatakan bahwa pooled data atau data panel memiliki beberapa istilah seperti pooling of time series dan cross sectional observation, tapi arti dari keduanya adalah sama, yaitu gabungan data dari time series dan cross sectional. Data yang dilakukan pemodelan berupa panel adalah rasio keuangan dan harga saham dari tiaptiap perusahaan yang dipilih.

\section{HASIL DAN PEMBAHASAN Analisis Deskriptif}

Sebelum dilakukan analisis, perlu diketahui bahwa dari 13 total perusahaan yang terpilih sebagai sampel hanya 12 perusahaan. Hal ini berdasarkan laporan keuangan periode tahun yang diambil, yaitu dari tahun 2011 sampai 2016. Jumlah sampel perusahaan yaitu 12 × 3 triwulan x 6 tahun. Total sampel penelitian ini yaitu 216.Setelah itu, 216 sampel ini perlu dilakukan analisis deksriptif.

Berdasarkan Tabel 3, dapat dilihat bahwa harga saham pada 12 perusahaan otomotif dan komponen memiliki rata-rata (mean) sebesar Rp 4.021,71, harga terendah sebesar Rp. 1380, harga tertinggi sebesar Rp. 8300 dan standar deviasi sebesar 1.860.608.

Tabel 3 Hasil Analisis Statistik Deskriptif Data

Descriptive Statistics

\begin{tabular}{|l|r|r|r|r|r|}
\hline & N & Minimum & Maximum & Mean & Std. Deviation \\
\hline CR & 131 &, 00 & 3,73 & 1,6661 &, 78846 \\
DER & 131 &, 00 & 50,46 & 1,4566 & 4,41093 \\
ROA & 131 & -15 &, 80 &, 0360 &, 08088 \\
TATO & 131 &, 00 & 1,29 &, 4152 &, 23870 \\
PER & 131 & $-47,51$ & 190,97 & 24,9911 & 30,54193 \\
HS & 131 & 1380 & 8300 & 4021,70 & 1860,608 \\
Valid N (listwise) & 131 & & & & \\
\hline
\end{tabular}

Jurnal Riset Bisnis dan Investasi

Vol. 4, No. 3, Desember 2018

ISSN 2460-8211
Perusahaan otomotif dan komponen yang memiliki harga saham terendah adalah Goodyear Indonesia Tbk pada triwulan 1 tahun 2013, sedangkan perusahaan otomotif dan komponen yang memiliki harga saham tertinggi adalah Astra Internasional Tbk pada triwulan 3 tahun 2016.Selain itu, current ratio dari 12 perusahaan otomotif dan komponen memiliki rata-rata (mean) sebesar $1,6661 \%$, nilai terendah sebesar $0,00 \%$, nilai tertinggi sebesar 3,73\% dan standar deviasi sebesar $0,78846 \%$. Perusahaan otomotif dan komponen yang memiliki nilai CR terendah adalah Nipress Tbk pada triwulan 3 tahun 2012, sedangkan perusahaan otomotif dan komponen yang memiliki nilai CR tertinggi adalah Selamat Sempurna Damai Tbk pada triwulan 1 tahun 2016. Lain halnya dengan debt to equity ratio dari 12 perusahaan otomotif dan komponen memiliki rata-rata (mean) sebesar 1,4566 nilai terendah sebesar 0,00 nilai tertinggi sebesar 50,46 dan standar deviasi sebesar 4,41093.Perusahaan otomotif dan komponen yang memiliki nilai DER terendah adalah Indospring Tbk pada triwulan 2 tahun 2012, sedangkan perusahaan otomotif dan komponen yang memiliki nilai DER tertinggi adalah Selamat Sempurna Damai Tbk pada triwulan 2 tahun 2014.Sementara itu, return on assets dari 12 perusahaan otomotif dan komponen memiliki rata-rata (mean) sebesar $0,0360 \%$ nilai terendah sebesar $-0,15 \%$ nilai tertinggi sebesar $0,80 \%$ dan standar deviasi sebesar $0,08 \%$. Perusahaan otomotif dan komponen yang memiliki nilai ROA terendah adalah Multi Prima Sejahtera Tbk d.h Lippo Enterprises Tbk pada triwulan 3 tahun 2015, sedangkan perusahaan otomotif dan komponen yang memiliki nilai ROA tertinggi adalah Indospring Tbk pada triwulan 3 tahun 2011.Total assets turnover dari 12 perusahaan otomotif dan komponen memiliki rata-rata (mean) sebesar 0,4152 nilai 
terendah sebesar 0,00 nilai tertinggi sebesar 1,29 dan standar deviasi sebesar 0,23870. Perusahaan otomotif dan komponen yang memiliki nilai TATO terendah adalah Selamat Sempurna Damai Tbk pada triwulan 2 tahun 2012, sedangkan perusahaan otomotif dan komponen yang memiliki nilai TATO tertinggi adalah Goodyear Indonesia Tbk pada triwulan 3 tahun 2013. Terakhir yaitu price earnings ratio dari 12 perusahaan otomotif dan komponen memiliki rata-rata (mean) sebesar 24,9911 nilai terendah sebesar -47,51 nilai tertinggi sebesar 190,97 dan standar deviasi sebesar 30,54193.Perusahaan otomotif dan komponen yang memiliki nilai PER terendah adalah Indomobil Sukses Internasional Tbk pada triwulan 2 tahun 2016, sedangkan perusahaan otomotif dan komponen yang memiliki nilai PER tertinggi adalah Indomobil Sukses Internasional Tbk pada triwulan 1 tahun 2014.

Merujuk pada Tabel 4, hasil pengujian normalitas setelah dilakukan transformasi dan tidak mengikutsertakan outliers menunjukkan bahwa nilai residual/ Unstandardized Residual memiliki nilai signifikansi sebesar 0,135 yang mana lebih besar dari 0,05. Menurut Ghozali (2013) jika nilai Asymp. Sig. (2 tailed) lebih dari 0,05 maka data residual terdistribusi normal.

Tabel 4 Hasil Uji Normalitas One-Sample Kolmogorov-Smirnov Test

\begin{tabular}{|ll|r|}
\hline & & $\begin{array}{r}\text { Unstandardiz } \\
\text { ed Residual }\end{array}$ \\
\hline $\mathrm{N}$ & Mean & 131 \\
Normal Parameters & \\
& Std. Deviation & -.4166 \\
Most Extreme & Absolute & .78788 \\
Differences & Positive & .101 \\
& Negative & .101 \\
Kolmogorov-Smirnov Z & -.101 \\
Asymp. Sig. (2-tailed) & 1.161 \\
\end{tabular}

\section{Pengaruh Rasio Keuangan terhadap}

\section{Harga Saham}

\section{Analisis Persamaan Regresi}

Analisis persamaan regresi bertujuan untuk mengetahui hubungan yang linier antara dua variabel.

Tabel 5 Hasil Uji Regresi

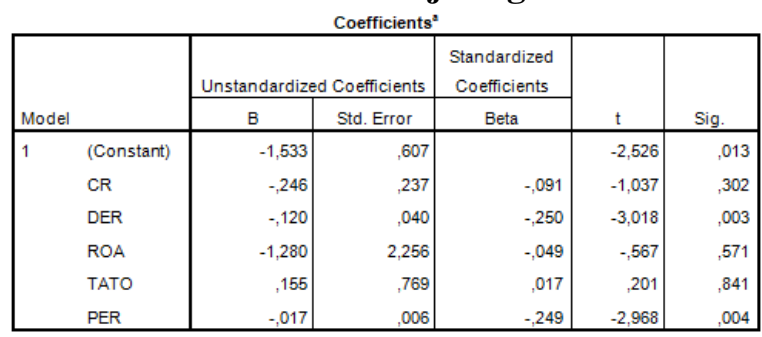

Persamaan regresi $\mathrm{Y}=-1,533-$ $0,246 \mathrm{X}_{1}-0,120 \mathrm{X}_{2}-1.280 \mathrm{X}_{3}+0,155 \mathrm{X}_{4}-$ $0,017 \mathrm{X}_{5}$ mengandung arti bahwa Nilai konstanta (a) sebesar -1,533. Selain itu, nilai koefisien regresi Current Ratio $\left(\mathrm{b}_{1}\right)$ sebesar -0,246 mempunyai arti bahwa jika Current Ratio menurun maka variabel Harga Saham akan meningkat, begitupun sebaliknya. Nilai koefisien regresi Debt Equity Ratio $\left(\mathrm{b}_{2}\right)$ sebesar -0,120 mempunyai arti bahwa jika Debt Equity Ratio menurun maka variabel Harga Saham akan meningkat, begitupun sebaliknya. Nilai koefisien regresi Return on Assets $\left(b_{3}\right)$ sebesar -1,280 mempunyai arti bahwa jika Return on Assets menurun maka variabel Harga Saham akan meningkat, begitupun sebaliknya. Nilai koefisien regresi Total Assets Turnover $\left(\mathrm{b}_{4}\right)$ sebesar 0,155 mempunyai arti bahwa jika Total Assets Turnover meningkat maka variabel Harga Saham akan meningkat pula, begitupun sebaliknya. Nilai koefisien regresi Price Earnings Ratio $\left(\mathrm{b}_{5}\right)$ sebesar -0,017 mempunyai arti bahwa jika Price Earnings Ratio menurun maka variabel Harga Saham akan meningkat, begitupun sebaliknya.

\section{Koefisien Determinasi}


Berdasarkan hasil analisis seperti pada Berdasarkan Tabel 6, nilai adjusted $R 2$ sebesar 0,155. Dengan demikian, dapat disimpulkan bahwa kemampuan variabel independen dalam menjelaskan variabel dependen sebesar $15,5 \%$. Sisanya sebesar $84,5 \%$ dijelaskan oleh variabel lain diluar model.Faktor-faktor lain yang mempengaruhi harga saham berdasarkan pandangan Islam et al. (2014) adalah makro ekonomi, mikro ekonomi, faktor yang berhubungan dengan perusahaan itu sendiri dan faktor lain.

Tabel 6 Hasil Uji Koefisien Determinasi Model Summary ${ }^{\circ}$

\begin{tabular}{|l|r|r|r|c|}
\hline Model & \multicolumn{1}{|c|}{ Model Summary } \\
\hline 1 &, $394^{2}$ &, 155 & \multicolumn{1}{c|}{$\begin{array}{c}\text { Adjusted } \mathrm{R} \\
\text { Square }\end{array}$} & $\begin{array}{c}\text { Std. Error of the } \\
\text { Estimate }\end{array}$ \\
\hline
\end{tabular}

\section{Uji Hipotesis}

Berdasarkan Tabel 5, hasil perhitungan pertama, diperoleh nilai signifikansi sebesar 0,302. Nilai signifikansi tersebut lebih besar dari taraf signifikan yang telah ditentukan yaitu 0,05. Maka berarti Ho diterima dan Ha ditolak, sehingga dapat disimpulkan bahwa CR tidak berpengaruh secara signifikan terhadap harga saham pada perusahaan otomotif dan komponen yang terdaftar di BEI tahun 2011-2016.Dari hasil perhitungan kedua, diperoleh nilai signifikansi sebesar 0,003. Maka berarti Ho ditolak dan Ha diterima, sehingga dapat disimpulkan bahwa DER berpengaruh secara signifikan terhadap harga saham perusahaan otomotif dan komponen yang terdaftar di BEI tahun 2011-2016. Dari hasil perhitungan ketiga, diperoleh nilai signifikansi sebesar 0,571. Maka berarti Ho diterima dan $\mathrm{Ha}$ ditolak, sehingga dapat disimpulkan bahwa ROA tidak berpengaruh secara signifikan terhadap harga saham perusahaan otomotif dan komponen yang terdaftar di BEI tahun 2011-2016.Dari hasil perhitungan keempat, diperoleh nilai signifikansi sebesar 0,841. Maka berarti Ho diterima dan Ha ditolak, sehingga dapat disimpulkan bahwa TATO tidak berpengaruh secara signifikan terhadap harga saham perusahaan otomotif dan komponen yang terdaftar di BEI tahun 20112016.Dari hasil perhitungan kelima, Dari hasil perhitungan, diperoleh nilai signifikansi sebesar 0,004. Maka berarti Ho ditolak dan Ha diterima, sehingga dapat disimpulkan bahwa PER berpengaruh secara signifikan terhadap harga saham perusahaan otomotif dan komponen yang terdaftar di BEI tahun 2011-2016.

Begitu juga dengan uji $F$ yang ditunjukan dengan Tabel 7. Apabila dilihat dari nilai $\mathrm{F}$ hitung $\mathrm{F}_{0}$ yang terlihat pada kolom $F$ yang besarnya 4,603 dengan menggunakantingkat signifikansi 0,05 serta $\mathrm{df}_{1}:(\mathrm{k}-1)=5-1=4$ dan $\mathrm{df}_{2}:(\mathrm{n}-\mathrm{k})=131-$ $4=127$, maka diperoleh $\mathrm{F}$ tabel $\left(\mathrm{F}_{1}\right)$ sebesar 2,44 yang berarti bahwa nilai $F_{0} \geq F_{1}$ yaitu $4,603 \geq 2,44$. Mengacu pada interpretasi hasil uji statistik F menurut Arikunto (2013: 268), jika kriteria $F_{0} \geq F_{1}$ dengan taraf signifikansi $5 \%$, maka interpretasinya adalah Ho ditolak dan $\mathrm{Ha}$ diterima, sehingga dapat disimpulkan bahwa seluruh variabel independen secara bersama-sama berpengaruh signifikan terhadap variabel dependen.

Tabel 7 Hasil Uji Hipotesis

\begin{tabular}{|ll|r|r|r|c|c|}
\hline Model & & Sum of Squares & df & Mean Square & F & Sig. \\
\hline 1 & Regression & 91,248 & 5 & 18,250 & 4,603 &, $001^{\circ}$ \\
& Residual & 495,628 & 125 & 3,965 & & \\
& Total & 586,876 & 130 & & & \\
\hline
\end{tabular}

\section{KESIMPULAN DAN SARAN}

Berdasarkan pengumpulan data, pengolahan data, dan analisis data yang dilakukan, maka bisa didapatkan kesimpulan:

1. Pengujian hipotesis current ratio terhadap harga saham menghasilkan nilai signifikansi sebesar 0,302 . Nilai 
signifikansi tersebut lebih besar dari taraf signifikan yang telah ditentukan yaitu 0,05. Dengan demikian, Ho diterima dan Ha ditolak. Nilai koefisien determinasi pada current ratio sebesar 0,062. Hal ini berarti variasi perubahan harga saham dipengaruhi oleh current ratio sebesar $6,2 \%$, sedangkan sisanya 93,8\% lainnya dipengaruhi oleh faktor lain. Berdasarkan hasil uji signifikansi, CR berpengaruh negatif dan tidak signifikan terhadap harga saham pada perusahaan otomotif dan komponen yang terdaftar di BEI tahun 2011-2016. Artinya, jika current ratio semakin menurun, maka harga saham akan semakin meningkat.

2. Pengujian hipotesis debt equity ratio terhadap harga saham menghasilkan nilai signifikansi sebesar 0,003. Nilai signifikansi tersebut lebih besar dari taraf signifikan yang telah ditentukan yaitu 0,05 . Dengan demikian, Ho ditolak dan Ha diterima. Nilai koefisien determinasi pada DER sebesar 0,076. Hal ini berarti variasi perubahan harga saham dipengaruhi oleh DER sebesar 7,6\%, sedangkan sisanya $92,4 \%$ lainnya dipengaruhi oleh faktor lain. Berdasarkan hasil uji signifikansi, DER berpengaruh negatif dan tidak signifikan terhadap harga saham pada perusahaan otomotif dan komponen yang terdaftar di BEI tahun 2011-2016. Artinya, jika debt equity ratio semakin menurun, maka harga saham akan semakin meningkat.

3. Pengujian hipotesis return on assets terhadap harga saham menghasilkan nilai signifikansi sebesar 0,571. Nilai signifikansi tersebut lebih besar dari taraf signifikan yang telah ditentukan yaitu 0,05. Dengan demikian, Ho diterima dan Ha ditolak. Nilai koefisien determinasi pada ROA sebesar 0,012. Hal ini berarti variasi perubahan harga saham dipengaruhi oleh ROA sebesar 1,2\%, sedangkan sisanya $98,8 \%$ lainnya dipengaruhi oleh faktor lain. Berdasarkan hasil uji signifikansi, ROA berpengaruh negatif dan tidak signifikan terhadap harga saham pada perusahaan otomotif dan komponen yang terdaftar di BEI tahun 2011-2016. Artinya, jika return on assets semakin menurun, maka harga saham akan semakin meningkat.

4. Pengujian hipotesis total assets turnover terhadap harga saham menghasilkan nilai signifikansi sebesar 0,841. Nilai signifikansi tersebut lebih besar dari taraf signifikan yang telah ditentukan yaitu 0,05 . Dengan demikian, Ho diterima dan Ha ditolak. Nilai koefisien determinasi pada TATO sebesar 0,008. Hal ini berarti variasi perubahan harga saham dipengaruhi oleh TATO sebesar 0,8\%, sedangkan sisanya $99,2 \%$ lainnya dipengaruhi oleh faktor lain. Berdasarkan hasil uji signifikansi, TATO berpengaruh positif dan tidak signifikan terhadap harga saham pada perusahaan otomotif dan komponen yang terdaftar di BEI tahun 2011-2016. Artinya, jika total assets turnover semakin meningkat, maka tidak akan meningkatkan harga saham.

5. Pengujian hipotesis price earnings ratio terhadap harga saham menghasilkan nilai signifikansi sebesar 0,004. Nilai signifikansi tersebut lebih besar dari taraf signifikan yang telah ditentukan yaitu 0,05.. Dengan demikian, Ho ditolak dan Ha diterima.Nilai koefisien determinasi pada PER sebesar 0,080. Hal ini berarti variasi perubahan harga saham dipengaruhi oleh PER sebesar 8\%, sedangkan $92 \%$ lainnya dipengaruhi oleh faktor lain. Berdasarkan hasil uji signifikansi, PER berpengaruh negatif dan signifikan terhadap harga saham pada perusahaan otomotif dan komponen yang 
terdaftar di BEI tahun 2011-2016. Artinya, jika price earnings ratio semakin menurun, maka harga saham akan semakin meningkat.

Adapun saran yang diberikan berdasarkan hasil kesimpulan diatas adalah sebagai berikut:

1. Bagi Bursa Efek Indonesia (BEI)

Bursa Efek Indonesia perlu menampilkan laporan keuangan dari masing-masing perusahaan secara lengkap dari tahun ketahun dikarenakan laporan yang ditayangkan di website resmi BEI hanya laporan keuangan untuk tahun terbaru. Selain itu, ada beberapa perusahaan yang menyisipkan laporan keuangan mereka dengan angka yang sangat fluktuatif. Meskipun terdapat pemeriksaan rutin untuk penyaringan dalam kategori LQ45, ada baiknya jika BEI menindak lanjuti perusahaan yang menyertakan laporan keuangan dengan nilai yang fluktuatif agar penelitian yang melibatkan perusahaan di luar kategori LQ45 dapat menghasilkan hasil yang sesuai. Seperti yang diketahui, LQ45 adalah indeks pasar saham di Bursa Efek Indonesia yang terdiri dari 45 perusahaan yang memenuhi kriteria tertentu.

2. Bagi Investor

Investor dalam mengambil keputusan berinvestasi saham pada perusahaan otomotif dan komponen, dapat memperhatikan kinerja keuangan perusahaan melalui rasio-rasio keuangan yang memiliki pengaruh secara signifikan terhadap harga saham. Berdasarkan penelitian ini rasio-rasio yang berpengaruh secara signifikan terhadap harga saham yaitu DER dan PER.

3. Bagi Perusahaan Sektor Otomotif dan Komponen/Emiten

Perusahaan harus mencantumkan laporan keuangan secara tepat waktu agar laporan keuangan keuangan perusahaan tersebut dapat disajikan di website BEI untuk kepentingan investor dan penelitian.

\section{DAFTAR PUSTAKA}

Arkan, T. (2016). The Importance of Financial Ratios in Predicting Stock Price Trends: A Case Study in Emerging Markets. Tesis. University of Szczecin: Kuwait

Badan Pusat Statistik. (2018). Perkembangan Jumlah Kendaraan Bermotor Menurut Jenis, 1949-2016. https://www.bps.go.id/linkTableDina mis/view/id/1133 [diakses tanggal 18 Maret 2018]

Darmaji, T., \& Henry, F. (2001). Pasar Modal di Indonesia. Jakarta: Salemba Empat.

Enekwe, C. I. (2015). The Relationship Between Financial Ratio Analysis and Corporate Profitability: A Study of Selected Quoted Oil And Gas Companies in Nigeria. European Journal of Accounting, Auditing and Finance Research, 3 (2).

Ghozali, I. (2013). Aplikasi Analisis Multivariate Dengan Program IBM SPSS 21 Edisi 7. Semarang: Penerbit Universitas Diponogoro.

Gujarati, D. N., \& Porter, D. C. (2009). Basic Econometric. Fifth Edition. New York: Mc-Graw Hill

Hery. (2015). Analisis Laporan Keuangan Pendekatan Rasio Keuangan. Yogyakarta: Center for Academic Publishing Service.

Islam, M. R., Khan, T. R., Choudhury, T. T., \& Adnan, A. M. (2014). How Earning Per Share (EPS) Affects on Share Price and Firm Value. European Journal of Business and Management, 6 (17), 97-108. 
KSEI. (2017). KSEI Terus Upayakan Kemudahaan Pembukaan Rekening Investasi. www.ksei.co.id. [diakses tanggal 7 Maret 2018]

Mujiono, H. P. (2017). Pengaruh CR, DER, ROA, dan EPS Terhadap Harga Saham Food and Beverages.Jurnal Ilmu dan Riset Manajemen, 6 (7).

Munawir. (2008). Analisis Laporan Keuangan Edisi IV. Yogyakarta: Liberty

Munggaran, A., Mukaram, \& Sarah, I. S. (2017). Pengaruh Earning Per Share (EPS) Terhadap Harga Saham. Jurnal Riset Bisnis \& Investasi, 3 (2), 3.
Najib, F. (2017). Pengaruh DPS, ROA, Inflasi dan Kurs Terhadap Harga Saham Pada Perusahaan Telekomunikasi. Jurnal Ilmu dan Riset Manajemen, 6 (7).

Nuhu, M. (2014). Role of Ratio Analysis in Business Decisions:A Case Study NBC Maiduguri Plant. Journal of Educational and Social Research, 4 (5).

Putri, I. O. A. (2015). Harga Saham dan Risiko Saham Untuk Menentukan Portofolio Saham Yang Efisien. Jurnal Ilmu dan Riset Manajemen, 4 (1). 